\title{
The implementation of Regional Medium Term Development Plan policy of Cianjur regency
}

\author{
Denny Aditya Dwiwarman \\ Universitas Putra Indonesia Cianjur \\ Email: dnnaditya@gmail.com
}

\begin{abstract}
Planning can be defined as determining the actions that will be carried out in the future with the aim of achieving what is desired. Planning is often arranged to solve a certain problem at a certain time. Planning is a continuous process, covering two aspects, namely the formulation of the plan and its implementation. Development is a process of implementing activities to make a better change as an application of a predetermined planning process. In the Cianjur Regency RPJMD 2011-2016, it is explained that the policy on public works is directed at road and bridge infrastructure programs, irrigation, water resources, building construction and rural infrastructure development. In accordance with the context of the problem to be studied, this research focuses more on road infrastructure based on tourism in South Cianjur which is expected to increase the purchasing power and welfare of the community, especially those in South Cianjur. This research uses qualitative research. A qualitative approach was chosen because it can be used to reveal and understand something behind a phenomenon that is not yet known or a phenomenon that is little known. The results showed that the implementation of the Cianjur Regency RPJMD policy was deemed not implemented properly, it was proven that good road conditions were around $36.35 \%$ and the rest was $64.65 \%$.
\end{abstract}

Keywords: Implementation; Policy; Regional Medium Term; Development

\section{INTRODUCTION}

National Development in developing countries, including Indonesia, prioritizes economic development. This is because developing countries are still experiencing problems in the economic field. In addition, economic development will support and stimulate reform and change in other life in society for the better (Bornstein et al., 2012; Hussain et al., 2012) .

The development planning system, which has tended to be uniform all this time, is starting to change and various variations appear depending on the potential and the main problems experienced by the region concerned (U. Farida et al., 2015; Umi Farida, 2017; Said et al., 2017; Suprapto \& Sunarsi, 2020). Regional development policies, which so far have only been a supporter of national policies, are beginning to undergo changes in accordance with the wishes and aspirations that develop in the regions. This situation causes the development planning patterns and systems in the autonomy era to undergo significant changes compared to what we have experienced in the era of centralization in the previous New Order government (Heilmann \& Melton, 2013).

Sjafrizal said that the changes that occurred were basically related to two main things, namely: first, regional governments were given greater authority in managing development 


\section{0| Jurnal Office: Jurnal Pemikiran Ilmiah dan Pendidikan Administrasi Perkantoran Vol. 7, Number 1, January-June 2021, Page 29-40}

(development decentralization). Second, local governments are given new sources of finance and greater financial management authority (fiscal decentralization). These two main points are intended so that local governments can be more empowered and able to make new creations and breakthroughs in order to encourage the development process in their respective regions in accordance with the potential and aspirations of the community concerned. The main objective and objective of drafting Law Number 25 of 2004 is to adapt the national and regional development planning system in effect in Indonesia with the principles of implementing such regional autonomy (Sjafrizal, 2012).

In connection with the achievement of these development goals, so that regional development runs efficiently and effectively, and the distribution of its benefits is evenly distributed throughout all villages and sub-districts, coordination and integration are important keywords in regional development. Development coordination in Indonesia began in earnest since the New Order, because in the previous period planning techniques were not well developed (Barker, 1998).

Each region has a long and short term development plan. Medium-term planning (medium-term planning) usually covers a period of 4-5 years, depending on the term of office of the president or head of the region. In Indonesia, medium-term planning has a term of 5 years that is drawn up by both the national and local governments. Basically, medium-term planning is a description of long-term planning so that it is more operational. Long-term planning consists of the formulation of a macroeconomic framework, strategies, policies and development programs based on the vision and mission of the elected president or regional head. In addition, mid-term planning also includes quantitative and qualitative development goals and targets so that these plans become more measurable and can be used as a basis for monitoring and evaluation (Marcellus, 2009; Zarenda, 2013).

In carrying out development, every regional government requires accurate planning and is expected to be able to evaluate the development that is being carried out. In line with the increasingly rapid development in the economic sector, there is an increase in demand for data and development indicators requiring data availability down to the district / city level. Data and development indicators that are needed are in accordance with predetermined plans.

The main key to the success of a development lies in the quality of the development planning. A planner must be able to formulate development in various sectors. Thus a development plan maker is required to have broad knowledge and insight in the development of an area based on all the potential that the area has. The sectors that should receive attention from a planner include the natural resource sector contained in the area, the socio-economic sector as well as the physical and infrastructure sectors (Blakely \& Leigh, 2013; Cvitanovic et al., 2015)

In this era of strategic management, planning in the regions must be preceded by first establishing a vision. The regional head provides a development vision in front of the DPRD, but the regional head's vision will not necessarily become the vision for autonomous regional development. This is because the DPRD, which becomes the people's representative, must see whether the development vision planned by the regional head is in accordance with the condition of the community and is supported by good human resources or not. In addition, the impact of development will benefit the wider community or only partially. 
Tourism is one of the mainstays of Cianjur Regency's Regional Original Revenue (PAD) and has an important role in the development of Cianjur Regency, given the many tourism potentials in Cianjur Regency. In the 2011-2016 RPJMD, the tourism sector is included in the third mission, namely "increasing people's purchasing power", with the aim of increasing coastal, natural and cultural-based tourism, which is able to compete to meet the needs of tourists, while still adhering to the principle of sustainable development (Puspitasari, 2018).

There are 18 tourism objects located in Cianjur Regency, divided into three tourism development areas, namely the North Cianjur region, the Central Region and the Southern Region, while those that have increased facilities and infrastructure, only 4 tourist areas, namely the Cibodas, Cikundul, Cirata and Jayanti Beach areas. located in Cidaun District, while the remaining 14 tourism potentials have not been given special attention to their development, such as Kukumbu Beach, Apra Beach and Sereg Beach, which are on the coast of South Cianjur.

Based on the description above, it can be seen that the development of the tourism sector, especially South Cianjur tourism, has not been effectively carried out by the local government of Cianjur Regency because there are still many damaged road accesses to potential destinations in South Cianjur beach as a marine tourism object, which has an attraction for local and foreign tourists, such as Pangandaran and Pelabuhan Ratu.

According to Lester and Stewart (2000) there are three reasons why policy changes or policy revisions are made, namely:

"Policy change is an increasingly common feature of policy formulation in contemporary western political systems. First, the government has, over the years, slowly expanded its activities in certain policy areas, so that there are some relatively new activities that could involve the government. Proposals for new policies may overlap, at least in parts, with existing programs. Second, the policy itself may create conditions requiring change because of insufficient results or conflicting results. Wrong legislative judgments may be an excuse for changing policies to make them work better. Third, the relative rate of sustainable economic growth, and the financial implications of existing policy commitments, means that room for movement to avoid problems of policy termination or policy change by rolling out a new program without cutting the old program is highly unlikely. Even if the government can identify a number of public policies which in its consideration are useless, wasteful, or not feasible, there will always be an opinion that says that the policies are useful and worth defending. Changing policies will always be easier than minimizing them, namely:"

On the other hand, (Sabatier, 1988) argues that basically policy change is seen as a product of changes in system-wide events, such as socio-economic disturbances or outputs from other subsystems, and competition between advocacy coalitions. in the subsystem to realize their important beliefs over time as they attempt to increase their resource base to respond to opportunities presented by external events, and to learn more about policy issues of interest to them. Based on the research background that has been stated above, the focus of this research is the implementation of the Cianjur Regency Medium Term Development Plan (RPJMD) policy 2011-2016 in the field of road development based on tourism in South Cianjur.

\section{METHOD}

The type of research used is descriptive research. Sugiyono defines "descriptive research is research conducted to determine the value of a variable without making comparisons, or 


\section{$32 \mid$ Jurnal Office: Jurnal Pemikiran Ilmiah dan Pendidikan Administrasi Perkantoran Vol. 7, Number 1, January-June 2021, Page 29-40}

linking one variable to another". Qualitative research is aimed at understanding social phenomena from the perspective of the participants. To study the participant's perspective, the author can use various strategies, interactive strategies, such as direct observation, participatory observation, in-depth interviews, documents, complementary techniques such as photographs. The basis of the research carried out is descriptive qualitative (Sugiyono, 2015).

A qualitative approach was chosen because it can be used to reveal and understand something behind a phenomenon that is not yet known or a phenomenon that is little known. In addition, qualitative methods can provide complex details about phenomena that are difficult to reveal by quantitative methods (Ritchie \& Ormston, 2003).

The arguments or reasons for using mixed research methods are seen as providing a more complete understanding of the issue or research problem than the use of one research method. Thus, this research is expected to be able to uncover problems in various perspectives regarding the implementation of the Cianjur Regency RPJMD policy in 2011-2016 in the field of road development based on South Cianjur Tourism. In addition, the emphasis on this mixed approach is based on the consideration that the focus of this research is directed at uncovering the process and finding meaning in depth and systematically about the implementation of the Cianjur Regency RPJMD policy in 2011-2016 in the field of road development based on South Cianjur Tourism, West Java Province.

\section{RESULT AND DISCUSSION}

The policy direction becomes a guideline for directing the implementation of formulated policies so that they are more focused in achieving development goals and targets within five years. The policy direction of the Cianjur Regency Government in the mid-term 2011 - 2016, started in 2012. This was due to the implementation of the inauguration of the newly elected Regent in May 2011. The policy direction in question can be explained as follows:

In 2012, development was focused on efforts to increase the capacity of development institutions and stimulate community participation in development in various fields with a focus on development and the 2011-2016 medium-term development goals. Therefore, the theme of development this year is to build a foundation for the medium term development of 2011-2016. Meanwhile, the policy direction can be explained by strengthening community empowerment, which is a prerequisite for the development of quality primary and secondary education.

The policy direction becomes a guideline for directing the implementation of formulated policies so that they are more focused in achieving development goals and targets within five years. The policy direction of the Cianjur Regency Government in the mid-term 2011 - 2016, started in 2012. This was due to the implementation of the inauguration of the newly elected Regent in May 2011. The policy direction in question can be explained as follows:

In 2012, development was focused on efforts to increase the capacity of development institutions and stimulate community participation in development in various fields with a focus on development and the 2011-2016 medium-term development goals. Therefore, the theme of development this year is to build a foundation for the medium term development of 2011-2016. Meanwhile, the policy direction can be explained by strengthening community empowerment, which is a prerequisite for the development of quality primary and secondary education. 
In 2015, the development focus continued to carry out several focuses which became the medium-term development goals while still taking into account the things that were the focus of development in the previous year, but with a lower intensity. The development theme in this period was to maintain the acceleration of development performance achievements. The policy direction in question is to maintain the quality of education towards standardized education, relevant to the needs of the business world, and capable of producing students with character;

In 2016, the development focus continued to carry out several focuses which became the medium-term development goals with the achievement of targets as targeted at the end of the planned year. The theme of development in this period was to strengthen the achievement of development performance towards community welfare. The policy direction in question is to strengthen the quality of education towards standardized education, relevant to the needs of the business world, and capable of producing students with character.

The Public Works Office of Bina Marga was formed based on Cianjur Regency Regional Regulation Number 07 of 2008 concerning Regional Government Organizations and the Establishment of Cianjur Regency Regional Apparatus Organizations. Meanwhile, the Public Works Sector is a vital regional government administration affair to encourage and support the functioning of development activities in other fields. Because there are links with various fields of development in the RPJMD 2011-2016, the field of Public Works Affairs, especially road construction, has contributed to the success of achieving the first, second, and third missions. The following is a list of tourist attractions in Cianjur Regency:

\section{Table 1}

\section{Tourist Attractions in Cianjur Regency}

\begin{tabular}{clc}
\hline No & \multicolumn{1}{c}{ Tourism site } & Location districts \\
\hline 1 & Istana Presiden Cipanas & Cipanas \\
2 & Kebun Raya Cibodas & Cipanas \\
3 & Makam Cikundul & Cikalong Kulon \\
4 & Kawasan Jangari & Mande \\
5 & Pantai Jayanti & Cidaun \\
6 & Makam Pangeran Hidayatulloh & Cianjur \\
7 & Gunung Padang & Campaka \\
8 & Gunung Jati & Cianjur \\
9 & Curug Citambur & Pasir Kuda \\
10 & Curug Cikondang & Pasir Kuda \\
11 & Batu Kasur & Pacet \\
12 & The Jhons Aquatiq Resort & Cianjur \\
13 & Taman Bunga Nusantara & Sukaresmi \\
14 & Kota Bunga & Sukaresmi \\
15 & Pantai Apra & Sindang Barang \\
16 & Pantai Sereg & Sindang Barang \\
17 & Pantai Kukumbung & Cidaun \\
18 & Museum Budaya & Cianjur \\
\hline
\end{tabular}

Source: Lakip Cianjur Regency ( 2011-2016: 88) 


\section{4| Jurnal Office: Jurnal Pemikiran Ilmiah dan Pendidikan Administrasi Perkantoran Vol. 7, Number 1, January-June 2021, Page 29-40}

In accordance with Law Number 38 of 2004 concerning roads, roads are part of the national transportation system which has an important role, especially in supporting the economic, social, cultural and environmental fields and is developed through a regional development approach in order to achieve a balance and equitable development of each region. forming and strengthening national unity to strengthen national defense and security, as well as forming a spatial structure in the context of realizing the means of national development.

The road as part of the transportation system is a medium that is needed by the community in order to meet their daily needs. The role of roads as part of the transportation system will not only support the development of an area but also increase the competitiveness of an area, which will also increase the competitive advantage of the region (Arnold et al., 2004).

The achievement of the regional government's mission is an important part of revealing the success of a region's development, including in Cianjur Regency. This is understandable considering that the achievement of the mission is closely related to the policy of the Regional Medium Term Development Plan. In this context, the discussion analysis will focus on the targets and programs that have been set in the Cianjur Regency RPJMD document for 20112016.

Referring to Law Number 38 of 2004 concerning Roads, and Government Regulation Number 34 of 2006 concerning Roads, the road network in Cianjur Regency can be grouped according to system, function, status and class.

\section{The grouping of roads according to the system consists of:}

The primary road network system, namely the road network system with the role of goods and services distribution services for the development of all regions at the national level, by connecting all distribution service nodes in the form of activity centers. The primary road network system is continuous, providing uninterrupted traffic services even though it is included in urban areas. Secondary road network system, namely a road network system with the role of service distribution of goods and services for people in urban areas.

2. The grouping of roads according to function consists of:

a. Arterial Road, which is a public road that serves main transportation with the characteristics of long-distance travel, high average speed and the number of entrances is efficiently limited.

b. Collector Road, is a public road that serves to serve collectors or dividers with the characteristics of moderate travel, medium average speed and limited number of entrances.

c. Local Roads, are public roads that serve local transportation with the characteristics of short-distance trips, low average speed and the number of entrances is not limited.

d. Environmental Roads, is a public road that serves environmental transportation with the characteristics of short-distance trips and low average speeds.

e. National roads, which are arterial roads and collector roads in the primary road network system that connects provincial capitals and strategic national roads and toll roads. The administration of national roads is carried out by the Directorate General of Highways of the Ministry of Public Works. Based on the decision of the Minister of Public Works 
(formerly the Minister of Settlements and Regional Infrastructure) Number: 376 / KPTS / M / 2004 concerning the Determination of Roads according to their status as national roads from 1,1140.69 Km long national roads in West Java Province along $63.66 \mathrm{~km}$ of which are in the Cianjur Regency area. The length of the National road sections in West Java Province changed to 1,351,132 Km and those in the Cianjur Regency area were changed to $71,294 \mathrm{Km}$ long, consisting of $39,827 \mathrm{Km}$ Arterial roads and 31,467 km collector roads.

The achievement of the mission is an action carried out by individuals, government and private groups, which are directed at achieving the goals and objectives, which become a priority in policy decisions. In simple terms it can be said that mission achievement includes all actions that take place between a statement or policy formulation and its actual impact. The success of achieving the mission towards targets and programs is determined, among others, through political, managerial and technical skills in translating the contents of the policy.

Therefore, to understand the public's or the parties' understanding of the mission achievements contained in the Cianjur Regency RPJMD 2011-2016, socialization is needed to ensure that the policy has been understood in substance before being implemented. The ability to understand or translate RPJMD policies in Cianjur Regency differs between the government as the implementer and the community as the object and target of the policy. At the apparatus level, not all parties involved are able to understand the RPJMD policies. At the executive level they only carry out program activities without knowing the planning, targets and objectives of development that have been planned by the Regional Development Planning Agency as stated in the RPJMD.

To find out in depth about the context of the research, the researcher then carried out the steps of a case study according to John W. Creswell, namely carrying out the stages of research including conducting interviews with predetermined informants. In line with this view, the results of interviews with the Regional Secretary of Cianjur Regency regarding the achievement of the mission towards the targets and programs that have been set in the Cianjur Regency RPJMD document for 2011-2016, especially regarding the achievement of the first mission "to increase the availability and affordability of quality education services?", obtained the following information (Fetters et al., 2013) :

"That the achievement of the first mission, it can be seen that the passing rates and graduation rates of SD, SMP / MTs, and SMA / MA, SMK show that Cianjur Regency students' graduation is still in the middle to lower ranks. The commitment outlined in this first mission is the hope of realizing the quality improvement given to students through increasing the achievement of graduation rates and graduation ratings of all levels of education only to achieve optimal levels are still far away due to budget constraints and the geographical area of Cianjur regency.

The results of the interview above mean that to achieve an optimal district mission requires cooperation of all parties and is supported by an adequate budget because the policies that are implemented can be viewed from the effectiveness of achieving the goals that have been set, the greater the achievement, the more effective the policy is implemented.

The above context is in line with the opinion of (Abdel-Wahab et al., 2013, hal. 107) states that: "A state policy will be effective if it is implemented and has a positive impact on 


\section{6| Jurnal Office: Jurnal Pemikiran Ilmiah dan Pendidikan Administrasi Perkantoran Vol. 7, Number 1, January-June 2021, Page 29-40}

members of society, in other words the actions or actions of humans who are members of society are in accordance with what the government or the State wants ". So the implementation of policies plays a very important role because after the policies are formulated, passed and communicated, the policies will not be useful if they are not implemented in a concrete manner in the field. Whether the policy formulation has been passed is realistic or not depends on how it is implemented in the field. Thus, one of the benchmarks for the success of a policy lies in the process of its implementation, where the most concern in policy implementation is "the perceived impact of community groups and competent superior institutions."

Based on the description above and the researcher's analysis through interviews and field observations, the impact of the ineffective achievement of the first mission contained in the RPJMD of Cianjur Regency, among others;

1. Not yet optimal road construction to access education

2. The integration and utilization of basic education data has not been carried out in an optimal and systematic manner and there are still problems with the level of economic capacity of the community which have an impact on the rate of continuing from SD / MI or equivalent to SMP / MTs or equivalent in an effort to complete 9 years of basic education.

3. Efforts to increase reading interest in the community have not been optimal and the provision of facilities and infrastructure for new classrooms and libraries and there has not been any cooperation with educational partners.

This is in accordance with the view of Anderson (1997) which states that policy implementation is seen from who implements the policy and its impact. It can be explained that every policy that has been set at the time of implementation is always preceded by the determination of an implementing unit which Anderson calls an "administrative unit", namely the ranks of the public bureaucracy from the top level to the lowest level and automatically implements the determined policies. Meanwhile, according to the view of Spitzer (2007) that the successful implementation of public policies can be seen through the dimensions of policy performance assessment with regard to; (a). Result dimension (difference between target and achievement), (b). Dimensions of the process of achieving results and learning, (c). Dimensions of resources used (efficiency and effectiveness), (d). Dimensions of existence and organizational development, (e). Leadership and learning dimensions.

The results of the study also found that the real development problems were inherent with the international, national, West Java Province, RPJPD and RTRW Cianjur Regency issues, as well as the policy implementation process. In addition, the successful implementation of infrastructure development policies, including road infrastructure, is strongly influenced by economic and social conditions, public support, attitudes and resources owned by groups, support from superior officials, commitment and leadership abilities of executing officials. Therefore, the RPJMD policy in the future requires strategic steps to design policies comprehensively and systematically.

The focus of the implementation of the RPJMD policy on road infrastructure development based on South Cianjur tourism. Meanwhile, the focus of the infrastructure development policy program in Cianjur Regency can be explained as follows: Development of stable and integrated road infrastructure between northern, central and southern regions to accelerate regional 
economic development. The realization of reliable regional infrastructure in supporting economic growth is one of the answers to the challenges faced by Cianjur Regency, which has a large area with geographic conditions in some parts of the region that are less stable, especially the South Cianjur region. The role of infrastructure that encourages connectivity between parts of the region can accelerate and expand economic development and increase people's purchasing power. The connectivity created by this infrastructure can lower transportation costs, which in turn increases the purchasing power and competitiveness of products and accelerates economic activity. The current condition of Cianjur Regency roads is still in a stable condition, still around $36.35 \%$ and the remaining $64.65 \%$ must be the focus of development in the future because the shift in planning paradigm from output to outcome can be seen from the success in achieving the vision and mission of the Regional Head. One of the successes of a policy can be seen from the ability of the policy to increase public satisfaction so that road infrastructure development is an acceleration of achieving development targets that prioritizes accessibility aspects.

In another position, "effectiveness is always related to the relationship between the expected results and the actual results achieved if the achievement of the goals of the organization is getting bigger, the greater its effectiveness". This view implies that if there is a greater achievement of goals than the organization, the greater the results that will be achieved from these goals. If after the implementation of public policy activities it turns out that the impact is not able to solve the problems currently facing the community, it can be said that a policy activity has failed, but sometimes a public policy results are not immediately effective in the short term, but after going through a certain process (Ayman et al., 2009).

Viewed from the perspective of public policy, (Abdel-Wahab et al., 2013) states as follows: "A state policy will be effective if implemented and have a positive impact on members of society, in other words the actions or actions of humans who are members of society are in accordance with what is wanted by the government or the state ". So the implementation of policies plays a very important role because after the policies are formulated, passed and communicated, the policies will not be useful if they are not implemented in a concrete manner in the field. Whether the policy formulation has been passed is realistic or not depends on how it is implemented in the field. Thus, one of the benchmarks for the success of a policy lies in the process of its implementation, where the most concern in policy implementation is "the perceived impact of community groups and competent superior institutions."

\section{CONCLUSION}

The realization of reliable regional infrastructure in supporting economic growth is one of the answers to the challenges faced by Cianjur Regency, which has a large area with geographic conditions in some parts of the region that are less stable, especially the South Cianjur region. The role of infrastructure that encourages connectivity between parts of the region can accelerate and expand economic development and increase people's purchasing power. The connectivity created by this infrastructure can lower transportation costs, which in turn increases the purchasing power and competitiveness of products and accelerates economic activity. The current condition of Cianjur Regency roads is still in a stable condition, still around $36.35 \%$ and 


\section{8| Jurnal Office: Jurnal Pemikiran Ilmiah dan Pendidikan Administrasi Perkantoran Vol. 7, Number 1, January-June 2021, Page 29-40}

the remaining $64.65 \%$ must be the focus of development in the future because the shift in planning paradigm from output to outcome can be seen from the success in achieving the vision and mission of the Regional Head. One of the successes of a policy can be seen from the ability of the policy to increase public satisfaction so that road infrastructure development is an acceleration of achieving development targets that prioritizes accessibility aspects.

\section{REFERENCES}

Abdel-Wahab, M., Richardt, G., Joachim Büttner, H., Toelg, R., Geist, V., Meinertz, T., Schofer, J., King, L., Neumann, F.-J., \& Khattab, A. A. (2013). High-speed rotational atherectomy before paclitaxel-eluting stent implantation in complex calcified coronary lesions: the randomized ROTAXUS (Rotational Atherectomy Prior to Taxus Stent Treatment for Complex Native Coronary Artery Disease) trial. JACC: Cardiovascular Interventions, 6(1), 10-19.

Arnold, P., Peeters, D., \& Thomas, I. (2004). Modelling a rail/road intermodal transportation system. Transportation Research Part E: Logistics and Transportation Review, 40(3), 255-270.

Ayman, R., Korabik, K., \& Morris, S. (2009). Is transformational leadership always perceived as effective? Male subordinates' devaluation of female transformational leaders 1. Journal of Applied Social Psychology, 39(4), 852-879.

Barker, J. (1998). State of fear: Controlling the criminal contagion in Suharto's New Order. Indonesia, 66, 7-43.

Blakely, E. J., \& Leigh, N. G. (2013). Planning local economic development. Sage.

Bornstein, M. H., Britto, P. R., Nonoyama-Tarumi, Y., Ota, Y., Petrovic, O., \& Putnick, D. L. (2012). Child development in developing countries: Introduction and methods. Wiley Online Library.

Cvitanovic, C., Hobday, A. J., van Kerkhoff, L., Wilson, S. K., Dobbs, K., \& Marshall, N. A. (2015). Improving knowledge exchange among scientists and decision-makers to facilitate the adaptive governance of marine resources: a review of knowledge and research needs. Ocean \& Coastal Management, 112, 25-35.

Farida, U., Akib, H., \& Jasruddin. (2015). Policy implementation of the national program for community empowerment in rural areas healthy and intelligent generation in Mamuju regency of West Sulawesi, Indonesia. International Journal of Economic Research, 12(5).

Farida, Umi. (2017). Analysis of Empowerment Program that was Implemented in Maтuju Regency East Sulawesi Indonesia. 149(Icest), 19-21.

Fetters, M. D., Curry, L. A., \& Creswell, J. W. (2013). Achieving integration in mixed methods designs-principles and practices. Health services research, 48(6pt2), 2134-2156. 
Heilmann, S., \& Melton, O. (2013). The reinvention of development planning in China, 19932012. Modern China, 39(6), 580-628.

Hussain, S., Sanders, E. B.-N., \& Steinert, M. (2012). Participatory design with marginalized people in developing countries: Challenges and opportunities experienced in a field study in Cambodia. International Journal of Design, 6(2).

Lester, J. (n.d.). P dan Joseph Stewart. 2000. Public Policy: An Evolutionary Approach.

Marcellus, I. O. (2009). Development planning in nigeria: reflections on the national economic empowerment and development strategy (NEEDS) 2003-2007. Journal of social sciences, 20(3), 197-210.

Puspitasari, I. (2018). Developing English For Tourism Materials Trough Stakeholders'needs Analysis. English Review, 7(1).

Ritchie, J., \& Ormston, R. (2003). The applications of qualitative methods to social research. Qualitative research practice: A guide for social science students and researchers, 24, e46.

Sabatier, P. A. (1988). An advocacy coalition framework of policy change and the role of policy-oriented learning therein. Policy sciences, 21(2), 129-168.

Said, F., Wahidiyat, A., Andayani, D. D., Harifuddin, H., \& Salam, R. (2017). Development of Travel Attractions Through the Design of Google SketchUp Based Coastal Tourist Map (Pengembangan Daya Tarik Wisata Melalui Perancangan Peta Wisata Pantai Berbasis Google SketchUp). Pekommas, 2(2).

Sjafrizal, S. (2012). Ekonomi Wilayah dan Perkotaan. Raja Grafindo Persada, Jakarta. PT. Raja Grafindo Persada.

Sugiyono, S. (2015). Qualitative and quantitative research methods and $R \& D$. Bandung: Alfabeta.

Suprapto, E., \& Sunarsi, D. (2020). The Effect Of the Implementation of Plant Lay Out the Rightand Availability of Raw Materials on the Production Flow In Indo Karuna Steel. International Journal of Education, Information Technology, and Others, 3(2), 1-9.

Zarenda, H. (2013). South Africa's National Development Plan and its implications for regional development. Stellenbosch: tralac, 35. 
40| Jurnal Office: Jurnal Pemikiran Ilmiah dan Pendidikan Administrasi Perkantoran Vol. 7, Number 1, January-June 2021, Page 29-40 